\title{
Unit of Frequency
}

National Cancer Institute

\section{Source}

National Cancer Institute. Unit of Frequency. NCI Thesaurus. Code C67313.

An indication of the type of unit of measure being used to express a number of regular events in a given time per unit of time. 